\title{
UROPHYSEAL CONTROL OF PLASMA IONIC CONCENTRATION IN Oreochromis mossambicus (PISCES) EXPOSED TO OSMOTIC STRESS
}

\author{
Bernardo Baldisserotto \\ Departamento de Fisiologia - Centro de Ciências da Saúde - UFSM - Santa Maria, \\ RS
}

Olga M. Mimura e Luiz C. Salomão

Departamento de Fisiologia - Instituto de Biociências - USP - São Paulo, SP

\section{RESUMO}

Exemplares de Oreochromis mossambicus adaptados à água doce e à água salgada foram submetidos a 5 tratamentos diferentes (urofisectomia, operação testemunho, injeção de extrato urofisário, injeção de salina e controle) e transferidos para água salobra. Nos peixes adaptados à água doce transferidos para água salobra a urofisectomia aumenta as concentrações de $\mathrm{Na}^{+}, \mathrm{K}^{+}$, $\mathrm{Ca}^{++}$e osmótica do plasma. Em peixes adaptados à água salgada transferidos para água salobra as concentrações plasmáticas de $\mathrm{Na}^{+}$e $\mathrm{K}^{+}$são mais baixas no grupo controle do que nos outros grupos experimentais. A urófise parece atuar apenas no "ajuste fino" dos processos osmorregulatórios. A adaptação às mudanças de salinidade do meio provavelmente são reguladas principalmente pela prolactina e pelo cortisol.

\section{SUMMARY}

Freshwater- and seawater-adapted Oreochromis mossambicus were submitted to 5 different treatments (urophysectomy, sham operation, urophyseal extract injection, saline injection and control) and transferred to brackish water. In freshwater- adapted fish transferred to brackish water, urophysectomy increases plasma $\mathrm{Na}^{+}, \mathrm{K}^{+}, \mathrm{Ca}^{++}$and osmotic concentrations. In seawater-adapted fish transferred to brackish water, plasma $\mathrm{Na}^{+}$and $\mathrm{K}^{+}$concentrations were lower in control than other treatment groups. The urophysis seems to act only in the "fine tuning" of osmoregulatory processes. Adaptations to changes in the salinity of the medium probably are regulated mainly by prolactin and cortisol. 


\section{INTRODUCTION}

Several studies have demonstrated structural changes in the caudal neurosecretory neurons when fish were exposed to different salinities, suggesting a relationship between the caudal neurosecretory system and osmoregulation (Chevalier, 1976; Mimura and Arnaez, 1984; ArnoldReed, et al., 1991).

The removal of the urophysis produces changes in ion balance in the eel (Chester Jones et al., 1969), goldfish (Turtle, 1974, see Bern and Nishioka, 1979) and snakehead (Woo and Tong, 1981). However, no significant effects on hydromineral metabolism were observed following urophysectomy in Fundulus (Imai et al., 1965), Gillichthys (Fryer et al., 1978) or Poecilia (Mimura and Arnaez, 1980).

The effects of urophysectomy on osmoregulation, however, are complicated for three main reasons possible regeneration in certain species (Tsuneki and Kobayashi, 1979); urophyseal hormones may be synthesized at multiple sites in the central nervous system outside the caudal neurosecretory system (Yulis and Lederis, 1986a,b); there is an increase in mortality after urophysectomy in a few species (Takasugi and Bern, 1962).

The injection of urophyseal homogenates has been reported to increase sodium influx (in the gills) and retention by the goldfish (Maetz et al., 1964), to produce natriuresis in freshwater eels (Bern et al., 1967) and to increase plasma sodium, chloride and magnesium concentrations in seawater Gillichthys (Fryer et al., 1978). However, urophyseal extracts decreased plasma sodium and chloride concentrations in $40 \%$ seawater-adapted Ophiocephalus but increased them in freshwater- adapted fish (Woo et al., 1980).

The differential effects of urophyseal manipulations have stemmed no doubt in part from species differences, but also from the fact that the urophysis elaborates several hormones each of which may have multiple sites of action (Larson and Bern, 1987). Chevalier (1976) proposed that the urophysis may be involved only in the "fine tuning" of osmoregulatory systems in response to alterations in salinity and may not be involved in major homeostatic adjustments associated with existence in a constant environment. In an attempt to confirm this hypothesis, one group of fish was urophysectomized and another injected with urophyseal extracts. Plasma ion concentrations were measured in both groups after exposure for $6 \mathrm{~h}$ to brackish water.

\section{MATERIAL AND METHODS}

Experimental animals - The present study was performed on male tilapia Oreochromis mossambicus $(50-150 \mathrm{~g})$ in the resting " $\mathrm{C}$ " stage of gonadal cycle (for classification see Daget 
1956). Tilapias of the same stage of gonadal development were used because the amount of urophyseal neurosecretory material may vary with gonadal stage (Fernandes and Mimura, 1983).Fish were collected in freshwater ponds in Oahu, Hawaii. They were brought to the Hawaii Institute of Marine Biology and acclimated to running freshwater or seawater $(35 \%)\left(24-27^{\circ} \mathrm{C}\right)$ for a period of one week prior to experimentation. During the experiment, fish were fed daily (Purina catfish growena) until 2 days prior to termination.

Surgical procedures - Fish were anesthetized with $0.3 \mathrm{ml} \mathrm{2-} \mathrm{phenoxyethanol/1} \mathrm{water} \mathrm{for} 10$ min. An incision was made about $1 \mathrm{~mm}$ above the lateral line and $1-2 \mathrm{~cm}$ anterior to the base of the tail fin. The neural arches were carefully removed and the urophysis and the posterior spinal cord above the four last vertebrae were removed. The incision was sutured and the fish were put back in aquaria containing $0.1 \mathrm{~g}$ furacin/l water for one day to minimize infection. One week after surgery, freshwater- and seawater-adapted fish were transferred to brackish water (15\%) for 6 hours prior to bleeding at the termination of the study. Sham-operated fish were submitted to the same surgical treatment except that the urophysis and posterior spinal cord were exposed but not removed.

Urophyseal extracts - Urophyseal extracts were prepared according to the method described by Ichikawa (1980). After diluting with saline $(0.7 \% \mathrm{NaCl}$ for freshwater-adapted fish and $0.9 \%$ $\mathrm{NaCl}$ for seawater-adapted fish), the urophyseal extracts $(0.1 \mathrm{ml})$ were administered intraperitoneally (one urophysis equivalent/fish). Freshwater-adapted fish received an extract with urophysis obtained from freshwater-adapted fish and seawater-adapted fish received an extract with urophysis collected from seawater-adapted fish. Injection of an equal volume of carrier solution served as control. After injection, freshwater and seawater fish were maintained in brackish water $(15 \%$ ) for 6 hours. Control groups were also transferred from freshwater or seawater to brackish water for 6 hours.

Sample collection and ion analysis were executed as described elsewhere (Mimura and Baldisserotto, 1988). Osmotic concentration was determined using a vapor pressure osmometer (Wescor, Ogden, Utah).

Statistical analysis - All data are presented as the mean \pm SE. The data of plasma ionic and osmotic concentration were tested for normality of distribution and homogeneity of variance using Bartlett's test (Sokal and Rohlf, 1969). Since variances of plasma potassium concentrations were significantly different, these data were submitted to a square-root transformation. Statistical significance among freshwater and seawater groups was assessed using one-way analysis of variance ("Microstat" program, Ecosoft), followed by the Student-Newman-Keuls multiple range test. The minimum significance level used for statistical testing was $\mathrm{p}<0.05$. 


\section{RESULTS}

Freshwater-adapted fish transferred to brackish water-Urophysectomy of freshwater-adapted tilapia caused a significant increase in plasma $\left[\mathrm{Na}^{+}\right],\left[\mathrm{K}^{+}\right],\left[\mathrm{Ca}{ }^{++}\right]$and osmotic concentration $(\mathrm{p}<0.05)$ compared with sham-operated controls (Fig. 1, 2, 3).
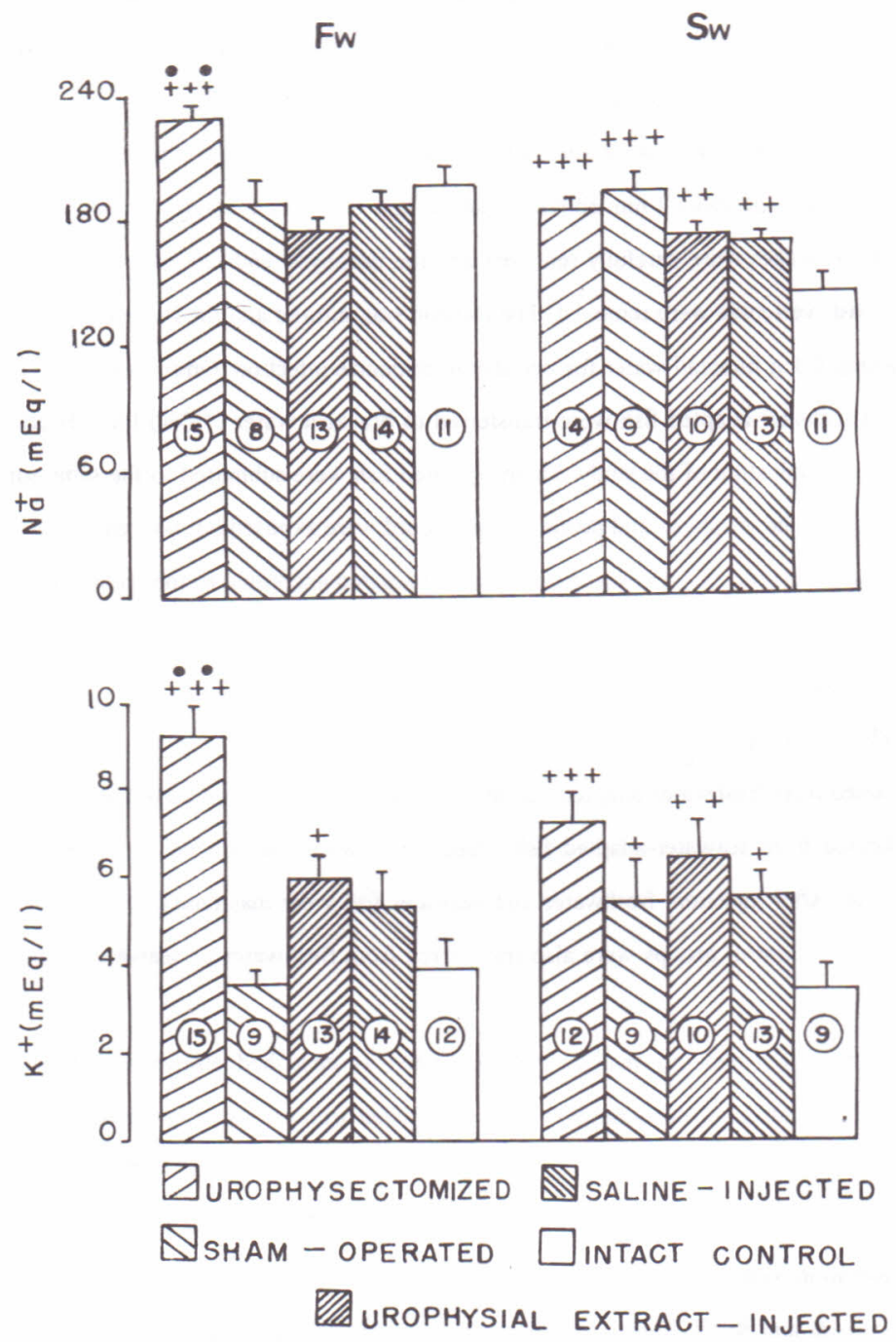

Figure $1-\mathrm{Na}^{+}$and $\mathrm{K}^{+}$concentration in the plasma of $(\mathrm{Fw})$ freshwater-adapted groups and (Sw) seawater-adapted groups of Oreochromis mossambicus, $6 \mathrm{~h}$ after transference to brackish water. Number of fish are in circles.

Difference of sham-operated group from urophysectomized group is indicated by

$\bullet \mathrm{p}<0.01$

and difference of control group from others groups by

$+\mathrm{p}<0.05++\mathrm{p}<0.01+++\mathrm{p}<0.001$ 

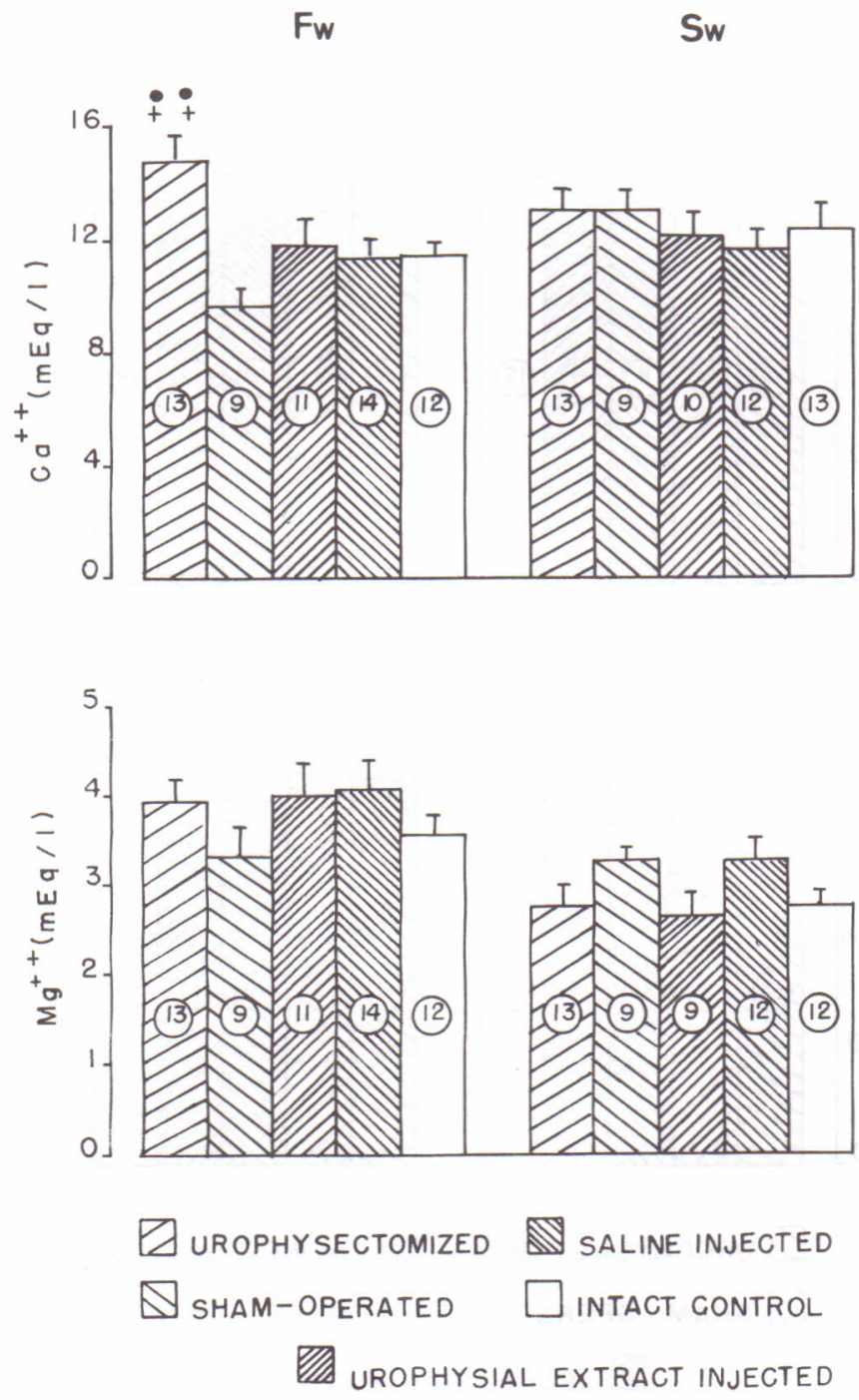

Figure $2-\mathrm{Ca}^{++} \mathrm{Mg}^{++}$concentration in the plasma of (Fw) freshwater-adapted groups and $(\mathrm{Sw})$ seawater-adapted groups of Oreochromis mossambicus, $6 \mathrm{~h}$ after transference to brackish water. Number of fish are in circles.

Difference of sham-operated group from urophysectomized group is indicated by - $\mathrm{p}<0.01$

and difference of control group from others groups by $++\mathrm{p}<0.01$ 
Fw

Sw
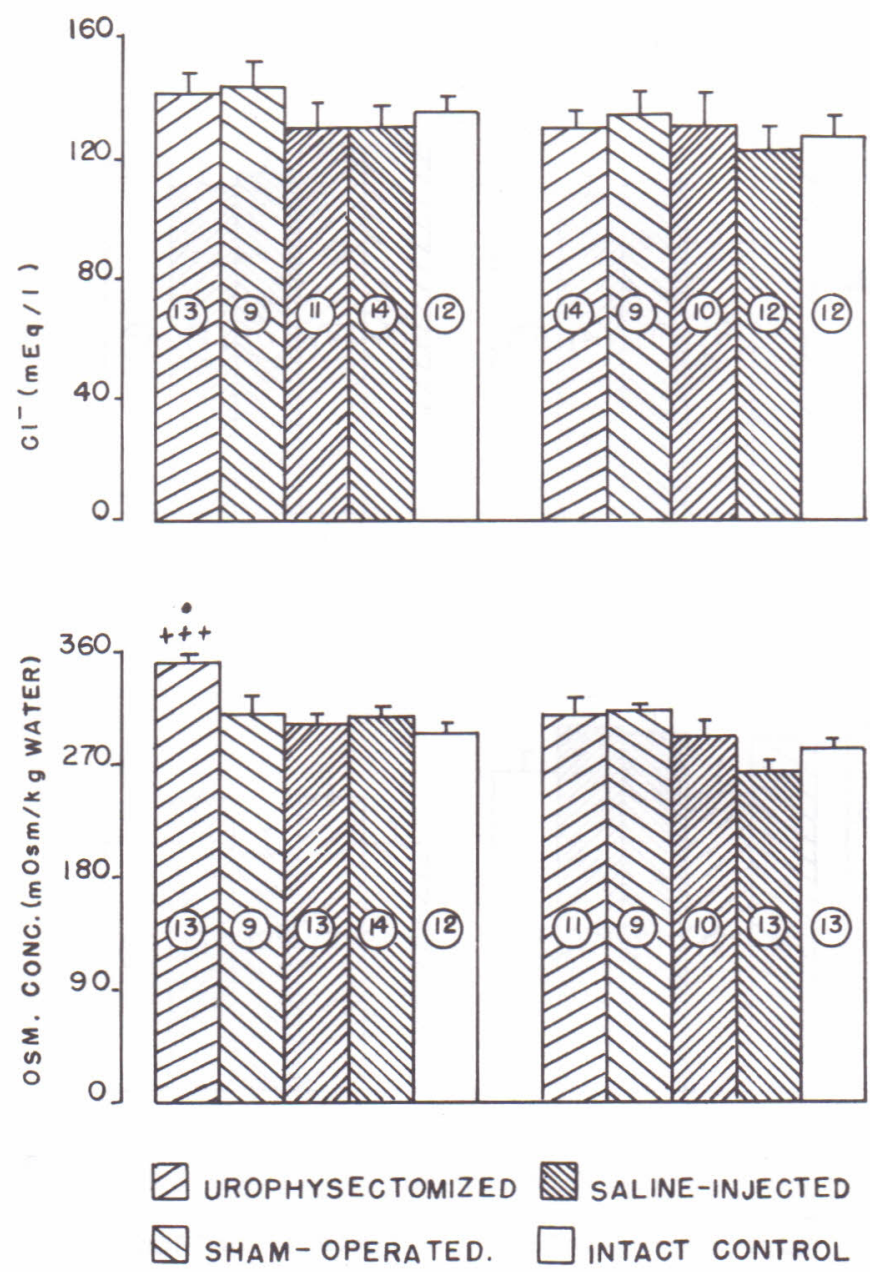

TUROPHYSIAL EXTRACT-INJECTED

Figure 3 - $\mathrm{Cl}^{-}$and osmotic concentration concentration in the plasma of (Fw) freshwater-adapted groups and (Sw) seawater-adapted groups of Oreochromis mossambicus, $6 \mathrm{~h}$ after transference to brackish water. Number of fish are in circles.

Difference of sham-operated group from urophysectomized group is indicated by - $\mathrm{p}<0.05$

and difference of control group from others groups by $+++p<0.001$ 
However, there were no differences in plasma $\left[\mathrm{Mg}^{++}\right]$and $\left[\mathrm{Cl}^{-}\right]$between urophysectomized and sham-operated fish (Fig 2,3). Sham-operation did not alter plasma ionic and osmotic concentrations compared with intact control levels. Moreover, there was no change in plasma ionic and osmotic concentrations following either urophyseal extract or saline injection (Fig. 1, 2, 3).

Seawater-adapted fish transferred to brackish water - No differences in plasma ionic and osmotic concentrations were observed among urophysectomized, sham-operated, urophyseal extract-injected and saline-injected fish (Fig. 1, 2,3). However, plasma $\left[\mathrm{Na}^{+}\right]$and $\left[\mathrm{K}^{+}\right]$were lower in intact control than in urophysectomized or sham-operated, urophyseal extract-injected and saline-injected fish $(\mathrm{p}<0.05)$ (Fig. 1).

\section{DISCUSSION}

Higher plasma ion and osmotic concentrations than other freshwater-adapted teleosts were found in freshwater-adapted O. mossambicus transferred to brackish water for $6 \mathrm{~h}$. In seawateradapted tilapia transferred to brackish water for $6 \mathrm{~h}$, plasma $\left[\mathrm{Na}^{+}\right],\left[\mathrm{K}^{+}\right]$and $\left[\mathrm{Cl}^{-}\right]$(mainly in control group) were lower than other seawater-adapted teleosts (Evans, 1979). These results are in agreement with the fact that transference of teleosts to a medium with lower or higher salinity reduces or increases (respectively) blood osmolality at the first hours, and just several hours later a new steady state is reached. Approximately $36 \mathrm{~h}$ for juvenile salmon, $12 \mathrm{~h}$ for flounder (Parry, 1966) and $24 \mathrm{~h}$ for Sciaenops ocellatus (Wakeman and Wohlschlag, 1983) were required for adjustment to comparable salinity changes. Thus, $6 \mathrm{~h}$ after transference of freshwater- or seawater-adapted tilapias to brackish water the equilibrium was not reached, and fish were still under osmotic stress.

The effects of urophysectomy on osmoregulation may be variable and complicated for several reasons, some of which have already been discussed. Urotensins I and II immunoreactivity in some neurons (IR-UI and IR-UII neurons) from the spinal cord and from brain regions were demonstrated. The apparent subdivision of the IR-UI and IR-UII neurons into two morphologically recognizable systems (the caudal or urophyseal and the rostral CSF spinal system) may be indicative of separated functions (Yulis and Lederis, 1986a,b). Also, the caudal neurosecretory system may regenerate shortly after urophysectomy in some species (Tsuneki and Kobayashi, 1979). In tilapia the caudal neurosecretory system regenerates 11-22 days after removal of the complete system (Fridberg et al., 1966). Consequently, in this study animals were sacrificed 7 days after urophysectomy. 
Urophysectomy in seawater-adapted $O$. mossambicus transferred to brackish water for $6 \mathrm{~h}$ did not change plasma osmotic and ionic concentrations in comparison with the sham-operated fish. Also, in seawater-adapted G. mirabilis (Fryer et al., 1978) and 40\% seawater-adapted O. maculatus (Woo and Tong, 1981), urophysectomy did not modify these physiological parameters.

Our results may appear to differ from the findings of an earlier study in which urophysectomized tilapia, adapted to hypertonic saline $(\mathrm{NaCl} 1.7 \%)$, showed elevated serum $\left[\mathrm{Cl}^{-}\right]$ (Takasugi and Bern, 1962). However, according to Imai et al. (1965), the absence of calcium in that saline could increase the osmotic stress compared with diluted seawater of the same osmolality. Our findings do not support the view of Imai et al. (1965), that urophysectomy in tilapia does not alter plasma $\left[\mathrm{Na}^{+}\right]$and $\left[\mathrm{Ca}^{++}\right]$. However, blood for analysis was collected two months after surgery in the earlier study and the caudal neurosecretory system may have fully regenerated by this time

Urophysectomy of freshwater-adapted O. mossambicus transferred to brackish water for $6 \mathrm{~h}$ led to a significant increase in plasma $\left[\mathrm{Na}^{+}\right],\left[\mathrm{K}^{+}\right],\left[\mathrm{Ca}^{++}\right]$and osmolality. $\left[\mathrm{K}^{+}\right]$and $\left[\mathrm{Ca}^{++}\right]$ elevations may be most easily explained by reduced urinary excretion of these ions compared with controls under similar conditions, a suggestion that has been made by Chester Jones et al. (1969) from studies on the freshwater-adapted, urophysectomized Anguilla anguilla. In freshwater-adapted O. maculatus, plasma $\left[\mathrm{Na}^{+}\right]$and $\left[\mathrm{Cl}^{-}\right]$diminished 9 days after urophysectomy (Woo and Tong, 1981). Urophysectomy also led to significant decrease in serum and plasma $\left[\mathrm{Na}^{+}\right]$in Catostomus and Carassius (Bern and Nishioka, 1979).

Urophyseal extract injections failed to modify plasma ionic and osmotic concentrations in freshwater- and in seawater- adapted tilapia. Similar observations were made by Bern and Nishioka (1979) in 5\% seawater-adapted G. mirabilis. Nevertheless, in seawater-adapted G. mirabilis, urophyseal extract injection led to an elevation of plasma $\mathrm{Na}^{+}, \mathrm{Cl}^{-}$and $\mathrm{Mg}^{++} 2-4 \mathrm{~h}$ after treatment (Fryer et al., 1978). In freshwater- adapted O. maculatus urophyseal extract injections have caused an increase in plasma $\mathrm{Na}^{+}, \mathrm{Cl}^{-}$and osmotic concentrations $3-5 \mathrm{~h}$ after treatment, and a decrease in plasma $\mathrm{Na}^{+}, \mathrm{K}^{+}$and $\mathrm{Cl}^{-}$in $40 \%$ seawater-adapted fish (Woo et al., 1980). The absence of a measurable effect after injection of urophyseal extract in the present study may be related to the dose utilized (one urophysis equivalent/fish) or to the fact that the urophysis contains multiple factors that may act antagonistically (Loretz et al., 1981). In addition, injections were made in intact fish and a negative feedback upon the urophysis may also contribute to the absence of observable action. Further study will be required to resolve this point.

In the present study, seawater-adapted $O$. mossambicus subjected to urophysectomy, sham operations, or injections (urophyseal extract and saline carrier) have suffered two kinds of stress: 
handling and change of medium. In teleosts, handling (Donaldson, 1981), and transition from a hyperosmotic to a hypoosmotic medium can increase plasma cortisol (Assem and Hanke, 1981). These stresses may well have led to high cortisol levels that would have inhibited gill $\mathrm{Na}^{+} / \mathrm{K}^{+}$. ATPase, as reported by Barton et al. (1985), which is likely to result in a decrease in $\mathrm{Na}^{+}$and $\mathrm{K}^{+}$ efflux. Consequently, fish submitted to the above treatments would have a significant increase in plasma $\left[\mathrm{Na}^{+}\right]$and $\left[\mathrm{K}^{+}\right]$.

On the other side, control group have suffered only the stress of change of medium, and effects of cortisol on osmoregulatory processes may vary with both dose and time of action. Small doses of cortisol has been shown to increase branchial $\mathrm{Na}^{+} / \mathrm{K}^{+}$-ATPase activity in seawater-adapted O. mossambicus (Dangé, 1986). This increase in the branchial $\mathrm{Na}^{+} / \mathrm{K}^{+}$-ATPase activity could cause a greater $\left[\mathrm{Na}^{+}\right]$and $\left[\mathrm{K}^{+}\right]$efflux, which would tend to decrease their plasma levels.

The same principle is not applied to freshwater-adapted $O$. mossambicus, because increase of cortisol levels due to stress would not have a significant effect, since branchial $\mathrm{Na}^{+} / \mathrm{K}^{+}$-ATPase activity remains almost unaffected by this hormone when fish are freshwater-adapted (Dangé, 1986).

In view of our results, the caudal neurosecretory system in $O$. mossambicus seems to act only in the "fine tuning" of osmoregulatory processes, as proposed by Chevalier (1976). Changes in the salinity of the medium (for example, from freshwater to brackish water or seawater to brackish water) probably are regulated mainly by prolactin and cortisol, as observed in other teleosts (Norris, 1985).

\section{ACKNOWLEDGMENTS}

We are thankful to Dr. E. Gordon Grau and Dr. N. H. Richman, from the University of Hawaii, and to Professor Howard A. Bern and R. S. Nishioka, from University of California, Berkeley, for their helpful advice during the experiments.

\section{REFERENCES}

Arnold-Reed, D.E.; Balment, R.J.; McCrohan, C.R. \& Hackney, C.M. 1991. The caudal neurosecretory system of Platichthys flesus: general morphology and responses to altered salinity. Comp. Biochem. Physiol., 99A: 137-143.

Assem, H. \& Hanke, W. 1981. Cortisol and osmotic adjustment of the euryhaline teleost, Sarotherodon mossambicus. Gen. Comp. Endocrinol., 43: 370-380. 
Barton, B.A.; Schreck, C.B.; Ewing, R.D.; Hemmingsen, A. \& Patiño, R. 1985. Changes in plasma cortisol during stress and smoltification in coho salmon, Oncorhynchus kisutch. Gen. Comp.

Endocrinol., 59: 468-471.

Bern, H.A. \& Nishioka, R.S. 1979. The caudal neurosecretory sys- tem and osmoregulation. Gunma Symposium Endocrinology, 16: 9-17.

Bern, H.A.; Nishioka, R.S.; Chester Jones, I.; Chan, D.K.O.; Rankin, J.C. \& Ponniah, S. 1967. The urophysis of teleost fish. J. Endocrinol., 37: xi.

Chester Jones, I.; Chan, D.K.O.; \& Rankin, J.C. 1969. Renal function in the european eel (Anguilla anguilla L.): effects of the caudal neurosecretory system, corpuscles of Stannius, neurohypophysial peptides and vasoactive substances. J. Endocrinol., 43: 21-31.

Chevalier, G. 1976. Ultrastructural changes in the caudal neuro- secretory cells of the trout Salvelimus fontinalis in relation to external salinity. Gen. Comp. Endocrinol., 24: 441-454.

Daget, J. 1956. Mèmoires sur la biologie des poissons du Niger Moyen. II. Recherches sur Tilapia zilli (Gerv.). Bull. Inst. Francais Afrique Noire, 18: 165-223

Dangé, A.D. 1986. Branchial $\mathrm{Na}^{+} / \mathrm{K}^{+}$-ATPase activity in freshwater or saltwater acclimated tilapia, Oreochromis (Sarotherodon) mossambicus: effects of cortisol and thyroxine. Gen. Comp. Endocrinol., 62: 341- 343.

Donaldson, E.M. 1981. The pituitary-interrenal axis as an indicator of stress in fish. In: Pickering, A.D. ed., Stress and Fish. Academic Press, New York, 11-47.

Evans, D.H. 1979. Fish. In: Maloiy, G.M.O. ed., Comparative Physiology of Osmoregulation in Animals. v. 1, Academic Press, London, 305-390.

Fernandes, M.N. \& Mimura, O.M. 1983. Caudal neurosecretory system of the brazilian freshwater teleost Geophagus brasiliensis (Quoi \& Gaimard, 1824); seasonal changes. Bolm. Fisiol. Animal USP, 7: 31-39

Fridberg, G.; Nishioka, R.S.; Bern, H.A. \& Fleming, W.R. 1966. Regeneration of the caudal neurosecretory system in the cichlid teleost Tilapia mossambica. J. Exp. Zool., 162: 311-336.

Fryer, J.N.; Woo, N.Y.S.; Gunther RL \& Bern HA (1978). Effect of urophysial homogenates on plasma ion levels in Gillichthys mirabilis (Teleostei, Gobiidae). Gen. Comp. Endocrinol., 35: 238- 244.

Ichikawa, T. 1980. Antidiuretic activity of teleost urophysial extracts in the rat. J. Comp. Physiol., 135: $183-189$

Imai, K.; Stanley, J.G.; Fleming, W.R. \& Bern, H.A. 1965. On the suggested osmoregulatory role of the teleost caudal neurosecretory system. Proc. Soc. Exp. Biol. Med., 118: 1102-1106 
Larson, B.A. \& Bern, H.A. 1987. The urophysis and osmoregulation. In: Pang, P.K.T. \& Schreibman, M.P. eds., Vertebrate Endocrinology: Fundamentals and Biomedical Implications. vol. II, Academic Press, New York, 143-156.

Loretz, C.A.; Bern, H.A.; Foskett, J.K.; \& Mainoya, J.R. 1981. The caudal neurosecretory system and osmoregulation in fish. In: Farner, D.S. \& Lederis, K . eds., Neurosecretion - molecules, cells, systems. Plenum Press, New York, 319-328.

Maetz, J.; Bourguet, J. \& Lahlou, B. 1964. Urophyse et osmoregulation chez Carassius auratus. Gen. Comp. Endocrinol., 4: 401-414.

Mimura, O.M. \& Arnaez, R.H. 1980. Sistema neurosecretor caudal de Poecilia vivipara (PISCES, TELEOSTEI, CYPRINODONTIFORMES) e concentração osmótica. Bolm. Fisiol. Animal USP, 5: 99-106.

Mimura, O.M. \& Arnaez, R.H. 1984. Sistema neurosecretor caudal de Poecilia vivipara (Block \& Schneider, 1801) - PISCES, CYPRINODONTIFORMES - Influência da salinidade. Bolm. Fisiol. Animal USP, 8: 33-41.

Mimura, O.M. \& Baldisserotto, B. 1988. Plasma ionic and osmotic concentrations of two freshwater teleost, Prochilodus affinis and Prochilodus marggravii in different gonadal stages. Bolm. Fisiol. Anim. S Paulo 12: 21-30.

Norris, D.O. 1985. Endocrine regulation of ionic-osmotic balance in teleosts. In: Norris, D.O. ed

Vertebrate Endocrinology, 2.ed., Lea \& Febiger, Philadelphia, 412-424

Parry, G. 1966. Osmotic adaptation in fishes. Biol. Rev., 41: 392-444.

Sokal, R.R. \& Rohlf, F.J. 1969. Biometry: the principles and practice of statistics in biological research. WH Freeman, San Francisco.

Takasugi, N. \& Bern, H.A. 1962. Experimental studies on the caudal neurosecretory system of Tilapia mossambica. Comp. Biochem. Physiol, 6: 289-303.

Tsuneki, K. \& Kobayashi, H. 1979. Regeneration of the caudal neurosecretory cells in the teleosts, Misgurmus anguillicandatus and Orizias latipes. Gunma Symposium Endocrinology, 16: 69.

Wakeman, J.M. \& Wohlschlag, D.E. 1983. Time course of osmotic adaptation with respect to blood serum osmolality and oxygen uptake in the euryhaline teleost, Sciaenops ocellatus (red drum). Contributions in Marine Science, 26: 165 - 177

Woo, N.Y.S. \& Tong, W.C.M. 1981. Urophyseal control of glucose metabolism and osmoregulation in the snakehead, Ophiocephalus maculatus. In: Farner, D.S. \& Lederis, K. eds.,

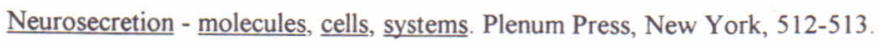

Woo, N.Y.S.; Tong, W.C.M. \& Chan, E.L.P. 1980. Effects of urophysial extracts on plasma 
electrolyte and metabolite levels in Ophiocephalus maculatus. Gen. Comp. Endocrinol., 41: 458466.

Yulis, C.R. \& Lederis, K. 1986a. Extraurophyseal distribution of urotensin II immunoreactive neuronal perikarya and their processes. Proc. Nat. Ac. Sci. USA, 83: 7079-7083.

Yulis, C.R. \& Lederis, K. 1986b. The distribution of "extra-urophyseal" urotensin Iimmunoreactivity in the central nervous system of Catostomus commersoni after urophysectomy. Neurosci. Let., 70: 75-80. 